\title{
STABILISASI TANAH GAMBUT PALANGKA RAYA DENGAN BAHAN CAMPURAN TANAH NON ORGANIK DAN KAPUR
}

\author{
Norseta Ajie S. ${ }^{(1)}$, Rida Respati ${ }^{(2)}$ \\ Dosen Program Studi Teknik Sipil UM Palangkaraya
}

\begin{abstract}
ABSTRAK
Secara umum Kota Palangka Raya memiliki jumlah sebaran tanah Gambut yang cukup besar.Hal tersebut selain menjadi keuntungan tetapi menjadi kerugian dalam bidang Insprastruktur.Tanah gambut memiliki persoalan tersendiri terhadap kekuatan daya dukung tanah dalam menahan beban lalu lintas di atasnya.Usaha perbaikan tanah gambut sering dilakukan dengan metode stabilisasi secara kimiawi yaitu melakukan pencampuran tanah gambut dengan bahan material tanah non organik (tanah granit) dan penambahan kapur dengan variasi 5\%,10\% dan 15\%. Stabilisasi yang dilakukan bermaksud memperkuat satu atau beberapa parameter dari sifat fisik maupun mekanik dari tanah asli yang ada.Proporsi campuran tanah kapur dan tanah non organik yang digunakan adalah $40 \%$ tanah gambut dan $60 \%$ tanah non organik.Dari hasil pengujian yang dilakukan yaitu penambahan variasi kapur pada campuran stabilisasi tanah gambut dan non organikterbukti dapat meningkatkan nilai California Bearing Ratio/ CBR yang diperoleh walaupun pada penambahan variasi pertama mengalami penurunan. Nilai CBR campuran tanah gambut dan non organiktanpa kapur diperoleh sebesar 7,79\%. Sedangkan pada penambahan kapur 5\% nilai CBR turun menjadi 5,89\%. Untuk selanjutnya pada penambahan kapur $10 \%$ dan 15\% secara berturut-turut CBR campuran tanah mengalami peningkatan masing-masing sebesar 9,74\% dan 11,59\%.Secara umum nilai CBR tanah campuran tanah gambut dan non organik telah memenuhi persyaratan sebagai bahan timbunan pilihan/subbase.Berdasarkan Klasifikasi tanah untuk CBR tanah timbunan pilihan berkisar dari 7\% - 20\%, kecuali untuk nilai CBR dengan penambahan kapur 5\%.
\end{abstract}

Kata kunci: gambut, kapur, tanah non organik, CBR 
Stabilisasi Tanah Gambut Palangka Raya ..., Norseta Ajie S. ${ }^{(1)}$, Rida Respati ${ }^{(2)}$

\section{PENDAHULUAN}

\section{Latar Belakang}

Kota Palangka Raya secara umum memiliki wilayah dengan kondisi tanah gambut dengan cakupan yang cukup luas.Perlu disadari bahwa pembangunan prasarana transportasi seperti jalan di atas tanah gambut menimbulkan banyak permasalahan. Permasalahan yang akan dihadapi antara lain mulai dari besarnya biaya yang harus dikeluarkan untuk pelaksanaan pembangunan sampai dengan metode yang dipilih dalam penanganan pembuatan bangunan di atas tanah gambut itu sendiri.

Salah satu Parameter yang menjadi tolak ukur dalam penentuan kemampuan tanah dalam pembuatan sarana transportasi sebagai jalan yaitu nilai daya dukung tanah adalah berupa nilai California Bearing Ratio (CBR).Persyaratan nilai daya dukung tanah dikatagorikan baik adalah apabila nilai CBR berdasarkan pengujian lapangan sebesar $\geq 3 \%$, dan berdasarkan laboratorium diperoleh nilai $\geq 6 \%$.Sedangkan tanah yang tidak mencapai pada syarat tersebut Tanah gambut cenderung memiliki nilai CBR yang rendah berkisar 2,595\% - 5,709 (Siti Hadijah, 2006).Berdasarkan hal di atas maka untuk tanah dengan nilai daya dukungnya kurang baik atau tidak cukup baik maka perlu dilakukan stabilisasi.

Stabilisasi tanah adalah usaha untuk merubah atau memperbaiki sifat-sifat teknis tanah agar memenuhi syarat teknis tertentu Maka dari kondisi yang ada diperlukan usaha stabilisasi untuk perbaikan kondisi daya dukung tanah gambut. Stabilisasi pada tanah gambut akan dilakukan secara kimiawi dengan menggunakan tanah non organik dan kapur sebagai bahan stabilisasi.

\section{Rumusan Masalah}

Adapun rumusan masalah dalam penulisan ini ialah:

a. Bagaimanakah karakteristik sifat-sifat tanah gambut di Palangka Raya?

b. Apakah indeks plastisitas (PI) tanah gambut mengalami perubahan setelah distabilisasi menggunakan tanah non organik dan kapur?

c. Apakah nilai CBR tanah gambut dapat mendapatkan nilai yang lebih baik setelah distabilisasi menggunakan tanah non organik dan kapur?

\section{Tujuan Penelitian}

Tujuan dari penelitian diantaranya ialah:

a. Memperoleh karakteristik sifat-sifat tanah gambut di Palangka Raya.

b. Mengetahui apakah indeks plastisitas (PI) tanah gambut mengalami perubahan setelah distabilisasi menggunakan tanah non organik dan kapur

c. Memperoleh nilai CBR tanah gambut setelah distabilisasi menggunakan kapur

\section{Batasan Masalah}

Adapun batasan masalah dari penelitian ini yaitu :

a. Sampel tanah gambut diambil di jalan Mahir Mahar (Lingkar Luar) Kota Palangka Raya ,

b. Sampel tanah non kohesif berupa tanah granit yang diambil dari kecamatan Bukit Batu Kota Palangka Raya.

c. Bahan aditif berupa kapur merupakan jenis kapur padam yang biasa digunakan untuk bahan bangunan.,

d. Contoh air menggunakan adalah air dilaboratorium Geoteknik Universitas Muhammadiyah Palangkaraya,

e. Penelitian ini dilaksanakan dilaboratorium 
Stabilisasi Tanah Gambut Palangka Raya ..., Norseta Ajie S. ${ }^{(1)}$, Rida Respati ${ }^{(2)}$

Geoteknik Universitas Muhammadiyah

Palangkaraya

\section{Manfaat Penelitian}

Manfaat penelitian ini antara lain:

a. Manjadi bahan rujukan terhadap salah satu upaya dalam penamfaatan tanah gambut yang telah di stabilisasi tanah gambut dengan bahan campuran tanah nonorganik dan kapur terutama di wilayah Palangka Raya

b. Mendapatkan hasil nilai California Bearing Ratio (CBR) yang dapat digunakan sebagai parameter peningkatan daya dukung tanah gambut distabilisasi dengan tanah non organik dan kapur.

c. Diharapkan dari penelitian ini dapat dijadikan dasar terhadap penelitian selanjutnya

\section{TINJAUAN PUSTAKA}

\section{Tanah Gambut}

Ciri khas dari tanah gambut adalah mengandung serat, kadar organik tinggi dan berwarna coklat sampai kehitaman. Tanah gambut mempunyai berat jenis yang kecil sehingga sangat ringan.Umumnya tanah gambut mempunyai sifat sebagai koloid kuat yang mampu mengikat air sehingga tanah gambut mempunyai kemampuan menyerap air yang tinggi.

Tabel 1. Klasifikasi tanah Gambut menurut ASTM

\begin{tabular}{|r|l|l|l|}
\hline A. & Berdasarkan Kadar Serat \\
\hline a. & Fibric & (Gambut mentah) & $>67 \%$ \\
\hline b. & Hemic & $\begin{array}{l}\text { (Gambut matang } \\
\text { sedang) }\end{array}$ & $33 \%-67 \%$ \\
\hline c. & Sapric & (Gambut matang) & $<33 \%$ \\
\hline
\end{tabular}

\begin{tabular}{|r|l|l|l|}
\hline B. & \multicolumn{3}{|l|}{ Berdasarkan Kadar Abu } \\
\hline a. & rendah & $:$ Kadar abu $<5 \%$ \\
\hline b. & sedang & $:$ Kadar abu 5-15\% \\
\hline c. & tinggi & $:$ Kadar abu > 15\% \\
\hline C. & Berdasarkan Daya Serap Terhadap Air \\
\hline a. & Kecil & $\begin{array}{l}: \text { Kapasitas menyimpan air < } \\
300 \%\end{array}$ \\
\hline b. & Moderat & $: \begin{array}{l}\text { Kapasitas menyimpan air } \\
300-800 \%\end{array}$ \\
\hline c. & Tinggi & $: \begin{array}{l}\text { Kapasitas menyimpan air } \\
800-1500 \%\end{array}$ \\
\hline d. & ekstrim & $: \begin{array}{l}\text { Kapasitas menyimpan air > } \\
1500 \%\end{array}$ \\
\hline D. & Berdasarkan Tumbuhan Pembentuk \\
\hline a. & $\begin{array}{l}\text { Terbentuk } \\
\text { dari satu } \\
\text { tumbuhan }\end{array}$ & $\begin{array}{l}: \text { Gambut kayu } \\
\text { Gambut Pakis (Kelakai) } \\
\text { Gambut eceng Gondok }\end{array}$ \\
\hline b. & $\begin{array}{l}\text { Terbentuk } \\
\text { dari } \\
\text { berbagai }\end{array}$ & $\begin{array}{l}: \text { Gambut daun lalang dan } \\
\text { pakis }\end{array}$ \\
\hline Sul
\end{tabular}

Sumber: Nugroho (2012)

\section{Kemampuan Menyerap Air (Absorbent)}

Kemampuan tanah gambut dalam menyerap dan menyimpan air (water holding) atau biasa dikenal dengan istilah absorbent tergantung dari kadar air tanah gambut yang dimiliki. Dalam ASTM standar (Standar Classification of Peat Samples by Laboratory, D 2980, Reapproved 1996), absorbent dibagi dalam beberapa jenis yaitu:

a. Extremely Absorbent, gambut dengan kemampuan menyimpan dan menyerap air $>1500 \%$.

b. Highly Absorbent, gambut dengan kemampuan menyimpan dan menyerap air antara $800 \%$ sampai dengan $1500 \%$.

c. Moderately Absorbent, gambut dengan kemampuan menyimpan dan menyerap air antara $300 \%$ sampai dengan $800 \%$.

d. Slightly Absorbent, gambut dengan kemampuan menyimpan dan menyerap air $<300 \%$. 
Stabilisasi Tanah Gambut Palangka Raya ..., Norseta Ajie S. ${ }^{(1)}$, Rida Respati ${ }^{(2)}$

\section{Indeks Plastisitas (PI)}

Indeks plastisitas (PI) adalah selisih batas cair (LL) dan batas plastis (PL) dan tanah masih bersifat plastis.Menurut Unified Soil Classification System (USCS) salah satu contoh tanah butir halus adalah tanah ini dibagi menjadi dua kelompok yaitu tanah butir halus yang sifat plastisnya rendah $(\mathrm{LL}<50 \%)$ dan sifat plastisnya tinggi ( $\mathrm{LL}>50 \%)$.

Tabel 2 Nilai Indeks Plastistas dan Macam Tanah

\begin{tabular}{|c|c|c|c|}
\hline PI & Sifat & $\begin{array}{c}\text { Macam } \\
\text { Tanah }\end{array}$ & Kohesifitas \\
\hline 0 & $\begin{array}{c}\text { Non } \\
\text { Plastis }\end{array}$ & Pasir & $\begin{array}{c}\text { Non } \\
\text { Kohesif }\end{array}$ \\
\hline$<7$ & $\begin{array}{c}\text { Plastis } \\
\text { rendah }\end{array}$ & Lanau & $\begin{array}{c}\text { Kohesif } \\
\text { sebagian }\end{array}$ \\
\hline $7-17$ & $\begin{array}{c}\text { Plastis } \\
\text { sedang }\end{array}$ & $\begin{array}{c}\text { Lempung } \\
\text { berlanau }\end{array}$ & Kohesif \\
\hline$>17$ & $\begin{array}{c}\text { Plastis } \\
\text { tinggi }\end{array}$ & Lempung & Kohesif \\
\hline
\end{tabular}

Sumber: Hardiyatmo (2006)

\section{Pemadatan (Compaction)}

Pengujian pemadatan digunakan dalam menentukan hubungan kadar air dengan berat volume, dan untuk mengevaluasi tanah agar memenuhi persyaratan kepadatan suatu campuran tanah. Menurut Proctor (1933) (Dalam Hardiyatmo, 2006), telah mengamati bahwa ada hubungan yang pasti antara kadar air dan berat volume kering tanah padat. Untuk berbagai jenis tanah pada umumnya, terdapat satu nilai kadar air optimum tertentu untuk mencapai berat volume kering maksimumnya.

\section{California Bearing Ratio (CBR)}

Uji CBR berasal dari Departemen Transportasi California tahun 1929.uji ini dimaksudkan untuk menentukan kelayakan suatu lapisan yanah yang akan digunakan sebagai subbase atau base course dalam konstruksi jalan raya. Sejak perang dunia kedua, U.S Army Corps of Engineers mengadaptasi uji ini untuk digunakan dalam konstruksi lapangan terbang.

Harga CBR digunakan untuk menilai kemampuan tanah, utamanya untuk digunakan sebagai base atau subbase di bawah perkerasan jalan atau lapangan terbang.

Tabel 3 Klasifikasi nilai CBR Tanah

\begin{tabular}{|c|c|c|}
\hline $\begin{array}{c}\text { CBR } \\
(\boldsymbol{\%})\end{array}$ & $\begin{array}{c}\text { Tingkatan } \\
\text { Umum }\end{array}$ & Kegunaan \\
\hline $0-3$ & Very poor & Subgrade \\
\hline $3-7$ & Poor to fair & Subgrade \\
\hline $7-20$ & Fair & Subbase \\
\hline $20-50$ & Good & Base or subbase \\
\hline$>50$ & Excellent & Base \\
\hline
\end{tabular}

Sumber: Bouwless (1992)

\section{METODE PENELITIAN}

Tahapan pelaksanaan penelitian yang akan dilaksanakan antara lain sebagai berikut :

a. Persiapan Peralatan dan bahan di laboratorium

b. Pengambilan sampel tanah gambut dan tanah non organik (granit)

c. Pengujian sampel tanah gambut

d. Pembuatan campuran tanah gambut dengan tanah non organik dan kapur

e. Pengujian campuran tanah gambut dengan tanah non organik dan kapur

f. Analisis hasil Pengujian untuk mempermudah tahapan pelaksanaan penelitian di atas dijelaskan seperti bagan alur penelitian pada berikut: 


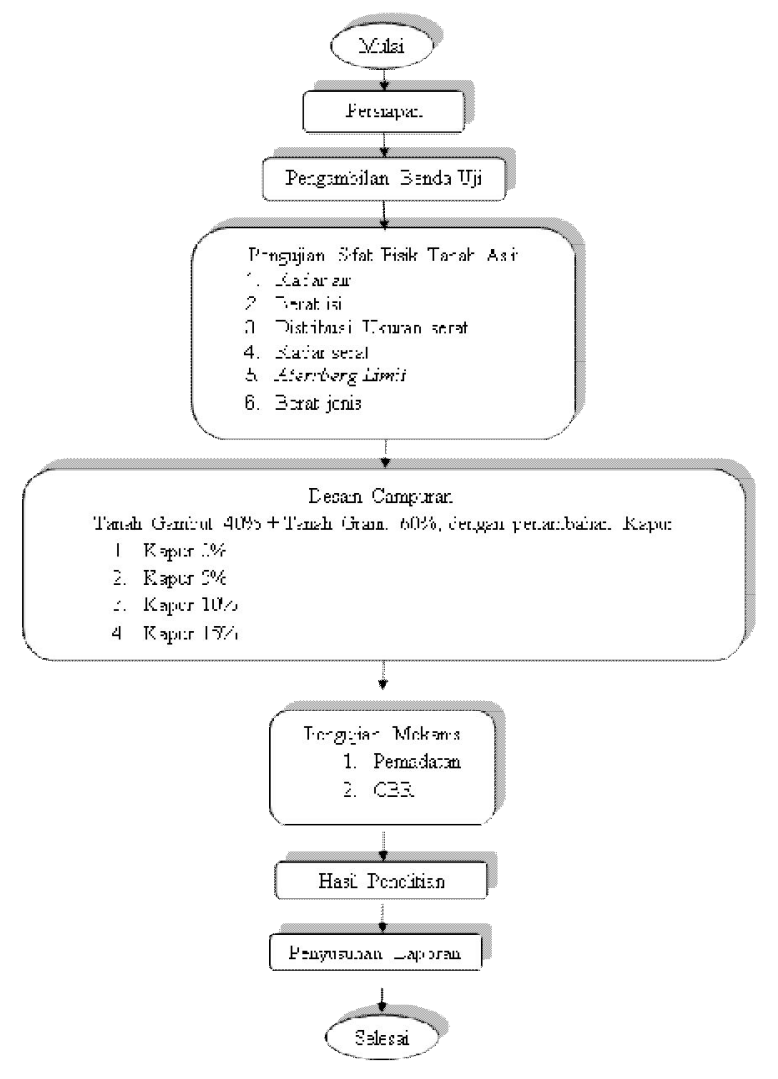

Gambar 2. Bagan Alur Penelitian

\section{HASIL DAN PEMBAHASAN}

\section{Karakteristik Tanah Gambut}

Setelah dilakukan penelitian di Laboratorium Geoteknik Fakultas Teknik UM Palangkaraya, diperoleh karakteristik tanah gambut kota Palangka Raya dapat dilihat pada tabel berikut.

Tabel 4. Karakteristik Tanah Gambut

\begin{tabular}{|l|c|c|}
\hline \multicolumn{1}{|c|}{ Jenis Pemeriksaan } & Satuan & Hasil \\
\hline Kadar Air Tanah & $\%$ & 134,70 \\
\hline Berat Isi Tanah & gr/cm3 & 1,11 \\
\hline Berat Jenis Rata-rata & & 1,35 \\
\hline Kadar Serat Rata-rata & $\%$ & 82,60 \\
\hline Batas Plastis & $\%$ & 0,00 \\
\hline Batas Cair & $\%$ & 0,00 \\
\hline Indeks Plastisitas & $\%$ & 0,00 \\
\hline
\end{tabular}

Sumber: Hasil Pengujian (2017)
Secara umum tanah gambut Palangka Raya memiliki Kadar air (water content) yang cukup tinggi yaitu $134,70 \%$, termasuk dalam kategori Slightly Absorbent yaitu tanah gambut dengan kemampuan menyimpan dan menyerap air kurang dari $300 \%$. Sedangkan berdasarkan hasil pengujian diperoleh rata-rata kadar serat sebesar $82,60 \%$ dan menurut ASTM maka tanah gambut termasuk dalam kategori gambut Fibric (Gambut mentah) dengan Kadar serat $>67 \%$.

Untuk nilai plastisitas tanah gambut Palangka Raya berdasarkan hasil pengujian diperoleh bahwa tanah tersebut termasuk dalam kategori non plastis.Hal tersebut dapat terjadi dikerenakan terjadinya pelapukan dari bahan organik yang terus melapisi tanah gambut yang ada.

\section{Pemadatan Tanah Gambut}

Pemadatan yang dilakukan adalah pemadatan tanah campuran yaitu hail pencampuran tanah gambut sebesar $40 \%$ dan tanah non organik (Granit) sebesar 60\%. Parameter yang diperoleh dari pengujian menggunakan standar proctor adalah nilai berat isi kering maksimum $\left(\gamma_{\mathrm{dmaks}}\right)$ dan kadar air optimum $\left(\mathrm{w}_{\mathrm{opt}}\right)$ seperti pada Gambar 3.

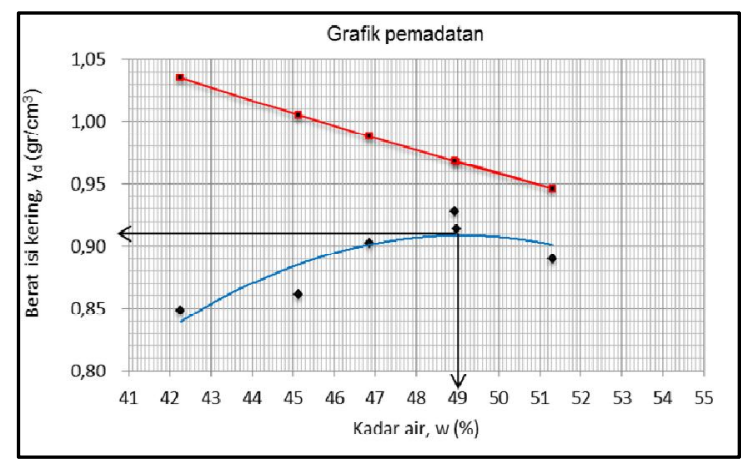

Gambar 3. Grafik Hasil Pemadatan 
Stabilisasi Tanah Gambut Palangka Raya ..., Norseta Ajie S. ${ }^{(1)}$, Rida Respati $^{(2)}$

Dari gambar diatas diperoleh berat isi kering maksimum $\left(\gamma_{\text {dmaks }}\right)$ adalah $0,91 \mathrm{gr} / \mathrm{cm} 3$ dan kadar air optimum $\left(\mathrm{w}_{\mathrm{opt}}\right)$ 49,00\%. Campuran tanah dipadatkan sebanyak tiga lapisan dengan tiap lapisan ditumbuk 25 kali dengan penumbuk beratnya $2,56 \mathrm{~kg}$ dan tinggi jatuh $30,50 \mathrm{~cm}$ dalam silinder mold dengan volume 902,75 cm3. Hasil dari pemadatan standar proctor ini merupakan parameter sebagai bahan untuk sampel pengujian California Bearing Ratio (CBR).

\section{California Bearing Ratio (CBR).}

Pengujian CBR laboratorium yang dilakukan adalah pengujian CBR yang bersifat rendaman (soaked.) Adapun sampel uji CBR kondisi harus direndam peram selama 1 hari dan dilakukan perendaman selama 5 hari. Untuk pengujian CBR ini adalah melakukan pengujian campuran tanah gambut $40 \%$ dan tanah nonorganik (granit) 60\% dengan penambahan kapur sebesar $0 \%, 5 \%, 10 \%$ dan $15 \%$ terhadap berat isi kering tanah.

Tabel 5.Hasil Pengujian CBR Tanah

\begin{tabular}{|c|c|c|c|}
\hline No. & Variasi Campuran & $\begin{array}{c}\text { Nilai } \\
\text { CBR (\%) }\end{array}$ & $\begin{array}{c}\text { Nilai } \\
\text { Swelling }\end{array}$ \\
\hline 1. & $\begin{array}{c}\text { Tanah Gambut + } \\
\text { Granit + Kapur 0\% }\end{array}$ & 7,79 & 0,96 \\
\hline 2. & $\begin{array}{c}\text { Tanah Gambut + } \\
\text { Granit + Kapur 5\% }\end{array}$ & 5,89 & 2,36 \\
\hline 3. & $\begin{array}{c}\text { Tanah Gambut + } \\
\text { Granit + Kapur } \\
10 \%\end{array}$ & 9,74 & 3,95 \\
\hline 4. & $\begin{array}{c}\text { Tanah Gambut + } \\
\text { Granit + Kapur } \\
15 \%\end{array}$ & 11,59 & 2,36 \\
\hline
\end{tabular}

Sumber: Hasil Pengujian (2017)
Dari data diatas dapat dilakukan perbndingan hasil pengujian yang dilaksanakan sebagai mana gambar dibawah ini.

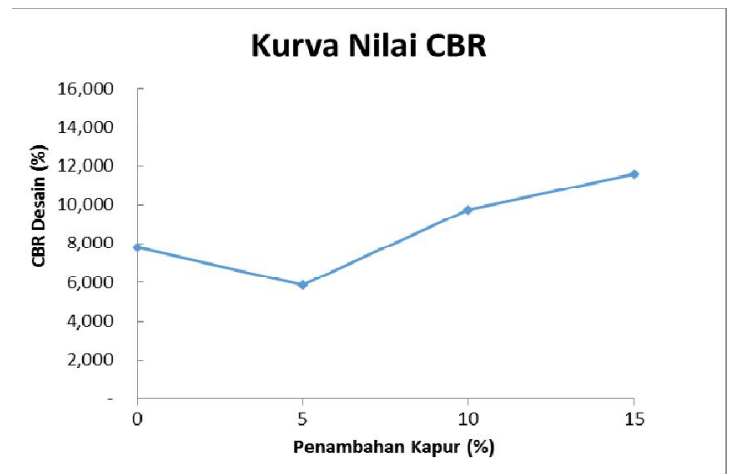

Gambar 4. Grafik Hubungan nilai CBR dengan Variasi Penambahan Kapur

Sedangkan untuk nilai Swelling yang dipengaruhi oleh proses perendaman sampel uji CBR yang mengakibatkan masuknya air kedalam rongga-ronga sampel tanah uji dapat dilihat pada Gambar 5berikut.

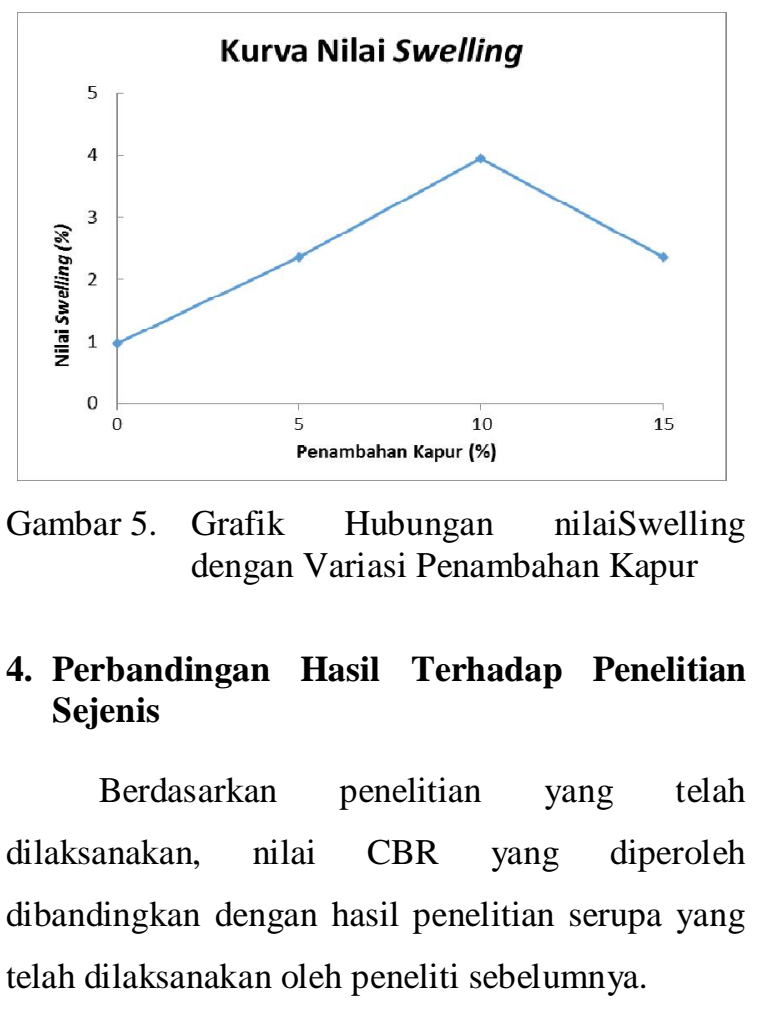


Stabilisasi Tanah Gambut Palangka Raya ..., Norseta Ajie S. ${ }^{(1)}$, Rida Respati ${ }^{(2)}$

Tabel 6 Nilai CBR Hasil Penelitian dengan Hasil Penelitian Sebelumnya

\begin{tabular}{|c|c|c|}
\hline No & Penelitian & $\begin{array}{c}\text { Nilai } \\
\text { CBR }(\%)\end{array}$ \\
\hline 1. & $\begin{array}{l}\text { Rakhman (2002), Stabilisasi Gambut } \\
\text { Rawa Pening dengan pencampuran } \\
\text { semen 5\% dan penambahan variasi } \\
\text { bahan material gypsum 5\%, 10\% dan } \\
15 \% \\
\text { a. Material Gypsum } 0 \% \\
\text { b. Material Gypsum 5\% } \\
\text { c. Material Gypsum 10\% } \\
\text { d. Material Gypsum 15\% }\end{array}$ & $\begin{array}{l}3,98 \\
5,18 \\
6,25 \\
4,00\end{array}$ \\
\hline 2. & $\begin{array}{l}\text { Hadijah, dkk (2006), Nilai CBR } \\
\text { Tanah Gambut Desa Bereng Bengkel, } \\
\text { Palangka Raya } \\
\text { a. CBR Soaked (Kering) } \\
\text { b. CBR Soaked (Basah) }\end{array}$ & $\begin{array}{l}0,97-3,57 \\
2,01-4,92\end{array}$ \\
\hline 3. & $\begin{array}{l}\text { Febri (2017), Karakteristik Tanah } \\
\text { Yang distabilisasikan Terhadap } \\
\text { Pembakaran } \\
\text { a. CBR Gambut + CaCO3 } 5 \% \text { dan } \\
\text { PCC 5\% } \\
\text { b. CBR Gambut + CaCO3 5\% dan } \\
\text { PCC 10\% } \\
\text { c. CBR Gambut + CaCO3 5\% dan } \\
\text { PCC 15\% }\end{array}$ & $\begin{array}{l}9,74 \\
10,99 \\
11,99\end{array}$ \\
\hline 4. & $\begin{array}{l}\text { Penelitian sekarang (2017) } \\
\text { a.CBR Gambut +Granit dan Kapur } \\
0 \% \\
\text { b.CBR Gambut + Granit dan Kapur } \\
5 \% \\
\text { c.CBR Gambut + Granit dan Kapur } \\
10 \% \\
\text { d. CBR Gambut + Granit dan Kapur } \\
\text { 15\% }\end{array}$ & $\begin{array}{c}7,79 \\
5,86 \\
9,94 \\
11,59\end{array}$ \\
\hline
\end{tabular}

akan dijelaskan perbandingan nilai-nilai CBR hasil penelitian (2017) dengan hasil penelitian sebelumnya sebagaimana pada Gambar di bawah ini.

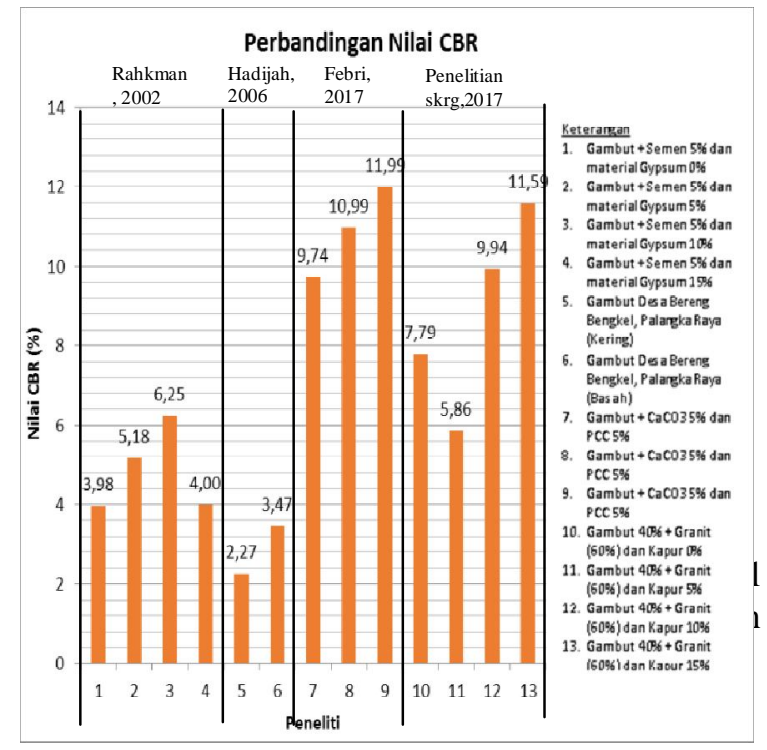

\section{KESIMPULAN DAN SARAN}

\section{Kesimpulan}

Dapat diambil kesimpulan hasil dari pengujian yang dilakukan antara lain:

a. Secara umum tanah gambut Palangka Raya memiliki Kadar air (water content) yang cukup tinggi yaitu $134,70 \%$, termasuk dalam kategori Slightly Absorbent, Sedangkan berdasarkan jumlah kadar serat yang dimiliki sebesar $82,60 \%$, maka tanah gambut tersebut masuk dalam kategori Fibrouse Peat.

b. Tanah gambut Palangka Raya yang diuji masuk dalam kategori Non Plastis dimana dari hasil pengujian yang dilakukan hampir tidak ditemukan kemampuan kelekatan tanah.

c. Penambahan kapur yang dilakukan pada campuran stabilisasi tanah gambut dan tanah granit terbukti dapat meningkatkan nilai California Bearing Ratio/ CBR yang diperoleh walaupun pada penambahan variasi pertama mengalami penurunan. Nilai CBR campuran tanah gambut dan tanah granit tanpa kapur diperoleh sebesar 7,79\%. Sedangkan pada penambahan kapur 5\% nilai CBR turun menjadi $5,89 \%$. Untuk selanjutnya pada penambahan kapur $10 \%$ dan $15 \%$ secara berturut-turut CBR campuran tanah mengalami peningkatan masing-masing sebesar $9,74 \%$ dan $11,59 \%$.

d. Secara umum nilai CBR tanah campuran tanah gambut dan granit telah memenuhi persyaratan sebagai bahan timbunan pilihan /subbase, kecuali untuk nilai CBR penambahan kapur 5\% pada campuran tanah. Sebagaimana Klasifikasi tanah berdasarkan nilai CBR bahwa CBR tanah timbunan pilihan berkisar dari $7 \%-20 \%$. 
Stabilisasi Tanah Gambut Palangka Raya ..., Norseta Ajie S. ${ }^{(1)}$, Rida Respati ${ }^{(2)}$

\section{Saran}

a. Perlu dipertimbangkan waktu pemeraman yang lebih lama untuk masing-masing pencampuran tanah gambut dengan kapur sebagai bahan stabilisasi.

b. Selain itu perlu dipertimbangkan kembali melakukan penambahan variasi campuran tanah gambut dan tanah granit dengan mencoba beberapa perbandingan persentase campuran.

c. Menginggat banyaknya parameter yang dilakukan dalam penelitian dapat dipertimbangkan kembali batasan waktu dalam melaksanakan penelitian.

\section{DAFTAR PUSTAKA}

Bowles, J.E, (1993), Sifat-sifat fisik dan Geoteknis Tanah, Erlangga, Jakarta Craig, R.F, (1987), Mekanika Tanah, Erlangga, Jakarta

Das, B.M, (1995), Mekanika Tanah (Prinsipprinsip Rekayasa Geoteknis),Erlangga, Jakarta

Febrie,H.R, (2017), Kakarteristik Tanah Gambut Yang Distabilisasi Terhadap Pembakaran, Jom FTEKNIK, Vol. 4, No.1, Universitas Negeri Riau, Pekan Baru.

Hardiyatmo, HC, (2006), Mekanika Tanah 1, Edisi Keempat, Gajah Mada University Press, Yogyakarta.

Hardiyatmo, H.C, (2010), Stabilisasi Tanah Untuk Perkerasan Jalan, Gajah Mada University Press, Yogyakarta.

Muda, Anwar (2011), Stabilisasi Tanah Lempung Bukit Rawi Menggunakan Pasir Dan Semen, Tesis, Program Studi Magister Teknik Sipil, Universitas Lambung Mangkurat, Banjarmasin
Nugroho, S.A., (2001), Stabilisasi Tanah Gambut Riau Menggunakan Campuran Tanah Non Organik dan Semen Sebagai Bahan Timbunan Jalan, Dinamika TEKNIK SIPIL/Vol. 12/No. 2/Mei 2012, Bandung. Rakhman, Y.A,(2002), Stabilisasi Tanah Gambut Rawa Pening dengan Semen dan Gypsum Syntetis (CaSO4.2H2O), Tesis, Program Studi Magister Teknik Sipil, Universitas Dipenogoro, Semarang

Soedarmo dan Purnomo (1997), Mekanika Tanah 1, Kanisius, Jogjakarta

Sukirman, S (1999), Perkerasan Lentur Jalan Raya, Nova, Bandung

Wesley, L.D, (1977), Mekanika Tanah, Cetakan ke VI, Badan Penerbit Pekerjaan Umum, Jakarta. 